ESJ Social Sciences

\title{
The Virtuous Circle of Intellectual Capital and Corporate Environmentalism: Evidence from the Food Industry
}

\author{
Eugenio D'Angelo, Associate Professor of Management \\ Pegaso Online University, Italy \\ Francesco Gangi, Full Professor of Management \\ Lucia Michela Daniele, PhD \\ Nicola Varrone, PhD \\ Unversità della Campania-Luigi Vanvitelli, Italy
}

Doi:10.19044/esj.2021.v17n1p1

Submitted: 16 October 2020

Accepted: 07 December 2020

Published: 31 January 2021

\author{
Copyright 2021 Author(s) \\ Under Creative Commons BY-NC-ND \\ 4.0 OPEN ACCESS
}

Cite As:

D'Angelo, E., Gangi F., Daniele L.M. \& Varrone N. (2021). The Virtuous Circle of Intellectual Capital and Corporate Environmentalism: Evidence from the Food Industry. European Scientific Journal, ESJ, 17(1), 1. https://doi.org/10.19044/esj.2021.v17n1p1

\begin{abstract}
The purpose of this paper is to address the relationship between intellectual capital and corporate environmentalism, assuming that intellectual capital may be an important precondition to foster environmental commitment and that, on the other side, corporate environmentalism may positively determine the level of intellectual capital in a reciprocal and virtuous circle. To address this topic, we conducted two OLS regression analysis on a worldwide sample of 235 firms operating in the food industry, over an eight years' time horizon (2010-2017), with 1,686 firm-year observations gathered from Asset-4ESG and Worldscope. Results confirm our hypotheses thus providing important theoretical and managerial implications.
\end{abstract}

Keywords: Intellectual capital, Corporate environmental responsibility, Food industry

\section{Introduction}

This study is a first answer to the call by Martín-de Castro \& Salmador (2019) for a deeper investigation concerning the relation between intellectual capital and corporate environmentalism. Undeniably, both of these themes of research are raising their prominence in the management field and combining 
them together may be extremely interesting for both theoretical and practical implications.

Indeed, since the Conference of Parties (COP) in the mid-90s, the entire world is improving its concern about environmental protection. In the last 20 years this commitment and awareness has led, on one side, to important negotiations such as the Kyoto Protocol (1995) or the Paris Agreement (2015) and, on the other side, to a higher non-normative pressure of the entire community on companies behavior (Albertini, 2018; Martín-de Castro et al., 2016). Furthermore, in 2020 the world is commemorating the 75th anniversary of the United Nations and this is giving the chance to assess the progress we are making towards the 17 Sustainable Development Goals (SDGs) of the 2030 Agenda. Most of these goals (clean water, affordable and clean energy, climate action, life below water and life on land), actually, are directly or indirectly related to the environment protection and, for this reason, corporate environmentalism will take more and more momentum from the moment on.

In this context, companies are implementing environmental strategies to respond to stakeholders' pressures or to gain a sustainable competitive advantage due to eco-innovations or cost reduction, but still there are several open questions when it comes to effective corporate environmentalism determinants and effects.

The purpose of this study is, therefore, to shed more light on these insights, assuming that intellectual capital may be an important prerequisite to turn environmental commitment in environmental performance and that, on the other side, corporate environmentalism may positively affect intellectual capital in a reciprocal and virtuous circle.

To test the aforementioned hypothesis, this work provides an empirical investigation in a highly concerned industry for environmental issues, such as the food. The remaining part of this work is organized as follows. The second section reviews previous literature, the third one formalizes the research hypothesis and the design of the empirical strategy. The fourth section of the study summarizes the results and the last section concludes, synthesizing the value and originality of the study and providing further research opportunities.

\section{Literature review}

Examining corporate social responsibility in a specific sector is certainly an approach to which literature is giving growing importance (Dabic et al., 2016). Sectoral characteristics affects stakeholder and community pressures in a substantial way and, therefore, they influence at the same time the prominence of the CSR topic (both theoretically and practically), the level of CSR engagement and the way firms orient their social and environmental practices (O'Connor and Shumate, 2010) and disclosure (Holder-Webb et. al. 2018). 
Sectoral studies concerning CSR are raising their prominence because some industries, more than others, are facing scandals that potentially can hit the all value chain and not only single corporations. Is the case, for instance, of the automotive sector or of the financial one (Siano at al., 2017; Gangi et al., 2019a).

In other cases, industry studies have raised their importance because they deal with primary human needs, for example, of the healthcare one (O'riordan \& Fairbrass, 2008).

In this perspective, it is evident that studying the food sector, more than other ones, can be important since it is characterized by a set of weaknesses depending both on endogenous and on exogenous factors and, therefore, is highly exposed to risks deriving from the unsustainable behavior.

The food sector has, indeed, both the previously mentioned characteristics to become an essential area of research when it comes to the CSR topic and particularly to the environmental pillar. On one side it has experienced a number of scandals in the last decades and, on the other, it is a crucial sector for environmental and social issues. In China, for example, scandals regarded the production of milk (2008), meat (2009-2013-2014), oil (2010) and noodles (2011). European and US food companies have experienced this kind of problems as well, particularly with reference to meat production (Bovine Spongiform Encephalopathy and the Pathogenic Avian Influenza), between 2005 and 2013 (Zhang \& Morse, 2018). Furthermore, the World Health Organization has many times stated that foodborne and waterborne disease kill millions of people annually (Aidara-Kanem, 2018). Therefore, is evident that environmental and social issues, in this sector, are highly interrelated and, for this reason, food companies' behavior is becoming of major interest (Hartmann, 2011).

Moreover, food firms typically have low margins, short products shelf lives and high short-term financial debt (particularly for companies that deal with seasoning production). Furthermore, natural calamities, diseases, weather vulnerability, animal diseases and volatility in commodity prices are all factors that can negatively affect the food sector strength and stability (Manning, 2016).

Additionally, the all food value chain extensively exploits the environment, probably more than other sectors (Maloni \& Brown, 2006). First, the agricultural sub-sector considerably employs natural resources, such as water and land, and therefore has an influence on the environment in terms degradation, biodiversity loss, climate change, toxic emissions and waste. Second, the processing sub-sector heavily impacts the environment too, mainly because of gas emissions and energy consumption. Finally, retailers also have an effect on the environment mostly because of packaging, waste and transportation. 
In order to guarantee sustainable production in the food industry, as mentioned in the previous section, authorities have set a bundle of regulations and procedures which may result, when it comes to consumers choices, in a "black box" vision of food products. In other words, consumers shouldn't care about food safety and pollution, since a higher level of supervision is in place. However, in this sector, where production is globalized (Ala-Harja, 2016), this will result in a major distance between producer and consumers. For these reasons, recently, consumers are responding by orienting their buying habits towards local producers, since local production is generally associated with some attributes such as freshness, seasonality and, finally, with a perceived higher degree of control (Brunori, 2016), despite the fact that small and local firms mostly lack in CSR engagement due to minor pressure from stakeholders (particularly of consumers, for the aforementioned "pretense of knowledge"), to a lack of resources and to the inconclusive cost-benefit relation between CSR engagement and economic performances.

Therefore, when there is a food scandal or just a simple concern, consumers begin to beware of the effectiveness of regulations and the mentioned lack of information turns into a lack of trust. For these reasons, consumers are more and more asking for additional information regarding CSR policies employed especially by big players in the food sector, in order to open the aforementioned black box and better orient their consumption habits, with evident effects on the importance of CSD (Gangi \& D'Angelo, 2016) and of reputation.

The CSR engagement, in the food industry, is therefore perceived to be a challenge mostly for big, global and listed companies than for small, unlisted and local ones. This statement is confirmed by previous researches that have demonstrated a significant effect of firm size on CSD even if some other authors state that, in order to mislead consumers, in response to their continuous request of information, significative green washing practices are also put in place in the food sector (Bazillier, 2013).

As we have seen, when it comes to CSR in the food sector, the issue of agricultural producers, processors and retailers cannot be treated separately, but rather has to be considered together and implemented through a wider sustainable value chain governance (Porter \& Kramer, 2011; Petit, 2018). Indeed, when a problem concerning social or environmental issues invest a single producer, it will be probably spread through the entire subsector (Våland \& Heide, 2005; Wiese \& Toporowski, 2013) and, therefore, assumes importance for the entire supply chain (Jorgensen et al. 2008; Meynard et al., 2017) that can be weakened or, in some cases, renovated. All the actors of the value chain have, therefore, a role in ensuring the sustainability of a food product in order to better integrate the impacts of their interactive activities, to facilitate a complex process which suffers a lack in data availability and to 
share the KPIs (Key Performance Indicators) to be monitored (Porter \& Kramer, 2011). Previous works confirm this broader view, highlighting that there is not significant correlation between the position in the supply chain and the level of CSD.

For all the aforementioned reasons, sustainability in the food sector is no more a desirable approach, but rather an imperative (Ala-Harja, 2016).

Furthermore it seems that there is a need for additional investigation in this sector also because previous contributions regarding CSR and particularly environmental responsibility, in the food industry, paid attention to several topics, such as efficiency (eco-innovation, resource reduction or emission reduction) or consumer behavior, but still, to the best of our knowledge, there are some important research gaps to be filled, particularly concerning determinants and effects of environmental performances.

From a theoretical point of view, CSR and, consequently, corporate environmentalism has been studied moving from the contrasting positions of Friedman and Freeman. Friedman stated that the only responsibility for managers was to make as much money as possible to maximize shareholder wealth. Assuming that responsible behavior is costly, in this perspective, firms should limit their commitment to environmental issues prescribed by law, because other kinds of behavior will imply managers acting as a State and imposing taxes to the shareholder (Friedman, 1970). This vision is clearly common with the opportunistic behavior described by agency theory (Jensen \& Meckling, 1976) and with the overinvestment and overconfident thesis (Goel \& Thakor, 2008; Barnea \& Rubin, 2010). On the other hand, as mentioned before, the stakeholder theory states that companies have responsibilities towards "any group or individual who can affect or is affected by the achievement of the organization's objectives" (Freeman, 1984). This broader vision, which is consistent with the communitarian position (Lashgari, 2004) and with the corporate responsibility continuum (Bhimani \& Soonwalla, 2005), assumes that firms are not anymore essentially perceived as a legal fiction and, therefore, it is not the formal contract between the firm and its stakeholders that shapes firms' need to satisfy stakeholders' expectations (Dunlop, 1998, Kendall, 1999) but, according to Mitchel et al. (1997), their power, legitimacy and urgency. As stated by Sharma \& Henriques, (2005) this vision is consistent with the one of Frooman (1999), who sees in the resource interdependence (Pfeffer \& Salancik, 1978) the capability of a stakeholder to affect corporate environmentalism directly or indirectly. For example government and regulators, in this view, are able ("have the power") to impose behavior to companies in a direct way, designing environmental regulation to encourage innovation (Porter \& van del Linde, 1995).

In this perspective, differently from Friedman's one, a firm can be defined socially responsible if it goes beyond the compulsory requirements 
given by law provisions and integrates social, environmental, ethical, human rights and consumer concerns into its strategies (Crifo et al., 2018). There is a wide body of literature investigating why firms should operate this way. Hart (1995), inspired by the resource-based view (Barney, 1991) and competitive advantage theory (Porter, 1980; Porter, 1985) formulated the Natural Resource Based View (NRBV). According to the resource-based perspective, firms can benefit from a sustainable competitive advantage (steaming from cost leadership or differentiation) only if its capabilities (such as technology, design, procurement, production distribution and service) are supported by valuable, firm specific and not easily imitable resources. Hart suggested that because of environmental growing concerns, the resource-based perspective needed a "natural" shift to remain relevant. This shift can be succeeded if firms are able to govern key resources to competitive advantage (continuous improvement, stakeholder integration and shared vision) in order to succeed in pollution prevention, product stewardship and sustainable development.

Synthesizing, there are two main reasons why companies enforce their environmentalism. On one side because they are subject to, direct and indirect, pressures from powerful stakeholders and, on the other side, because they perceive environmental engagement as a source of competitive advantage.

Both these motivations are strong, actual and consistent, especially in the food industry. However, there is still a missing link in shaping different kinds of behavior between firms operating in the same environment and, therefore, exposed to same pressures and having the same chances of creating competitive advantage through eco-innovations and resource and emission reduction.

\section{The link between Corporate Environmentalism and Intellectual Capital}

In our opinion, the aforementioned missing link may be found in the level of intellectual capital. Intellectual capital refers to human, structural and social capital of firms (Stewart, 1997; Youndt \& Snell, 2004) and it has the same structure when it comes to green intellectual capital (Chen, 2008). Human capital refers to employee's knowledge, abilities and skills that are essential for them to achieve their daily objectives. Social capital, on the other hand, refers to procedures and routines embedded in corporate culture. Relational capital deals with the value of relationships between the firm and the external environment (Gangi et al. 2019b).

All these aspects are firm specific in the way they are held by human resources, by the organization itself, or, finally, in the way they aid each other in interacting with the external environment. All these aspects are also rare and difficult to imitate thus completing all the RBV elements to determine a competitive advantage in the knowledge economy. 
Furthermore, it is evident that proactive management, oriented to competitive advantage, towards environmental practices is not the only reason why firms behave differently. The new institutional theory (DiMaggio \& Powell, 1983) states that firms, by conforming to the dominant practices can obtain legitimacy. However, Delmas \& Toffel (2008), when investigating corporate engagement to environmental concerns, contributes to this approach emphasizing that organizational characteristics affect the way firms respond to stakeholders' requirements, thus shaping differences among firms exposed to the same level of pressure (that is the case of the same sector for instance). Additionally, firms that do not have well-developed quality management processes could face barriers to pollution prevention because these strategies need the involvement of a large number of people, which is fundamental also for a sustainable development vision. On the other hand, product stewardship needs the involvement in the process of key stakeholders (suppliers and consumers).

\section{Research hypotheses and empirical strategy}

A higher level of intellectual capital, according to the NRBV, may assure companies to be able to lower their costs or to differentiate through ecoinnovations (Martin-de Castro, 2016) and, according to the institutional theory, may contribute to improve firms' capacity to react to external environment. These reasons lead us to hypothesize that:

Hpl. The level of intellectual capital positively affects the level of environmental performance

However, this direct and one-way relation between intellectual capital and environmental engagement is not the only way to look at these two companies 'attributes (Gangi et al., 2019b). According to Brekke \& Nyborg (2004) environmental commitment allows companies to attract, develop and retain better skilled human capital. In this way firms can achieve a double effect in terms of intellectual capital. On one side, they can improve the general level of knowledge of the workforce and, on the other side, they may improve long-term relations, thus favouring corporate culture and routines. Moreover, environmental engagement may improve firms' capability to interact and to be recognized by the external environment as a good citizen, thus improving relational capital. For these reasons, we formulate our second hypothesize as follows:

Hp2. The level of environmental performance positively affects the level of intellectual capital

The aforementioned two hypotheses, together, form a virtuous circle between intellectual capital and corporate environmentalism that results in a bidirectional relation. To test our hypotheses, we gathered longitudinal panel data from two databases. We employed the Asset4-ESG database (Thomson 
Reuters) for intellectual capital and environmental performance information and the Worldscope database to collect financial ones. However, financial data regarding food producer and retailer companies were available for a higher number of international public firms (333 with 2.592 firm-year observations) but, according to the purpose of the study, we had to combine the financial dataset with the ESG one, thus reducing our final sample to 235 firms, over an eight years' time horizon (2010-2017), with 1.686 firm-year observations. Furthermore, because of lagged variables, our final sample employed in the regression models consisted of 1,200 firms-year observations.

Asset4-ESG provides an overall score that measures corporate social responsibility, but also allows disentangling the comprehensive score in pillars such as environmental, corporate governance, social and economic ones. We exploit this possibility to gather measures that can proxy the level of intellectual capital and corporate environmental performance. In particular we measured our variables as follows.

$\mathrm{ENV}=$ The Environmental score is a variable that varies between 0 and 100. It "measures a company's impact on living and non-living natural systems, including the air, land and water, as well as complete ecosystems." It measures "how well a company uses best management practices to avoid environmental risks and capitalize on environmental opportunities in order to generate long term value" (ASSET4 ESG Data Glossary, 2018). This score weight for the $33 \%$ of the comprehensive ESG score, synthesizing and standardizing 70 measures related to three environmental sub-pillars, such as product innovation, resource reduction and emission reduction. The product innovation score measures the company's commitment and effectiveness towards R\&D in the area of eco-efficient products. It reflects a company's ability to reduce environmental costs and drains for its consumers and thus generating new opportunities through environmental technologies or ecodesigned products. The resource reduction score measures a company's commitment and efficacy towards attaining an efficient use of natural resources in its processes. It reveals the company's capability to reduce the use of materials, energy or water, and to find more eco-efficient solutions improving the supply chain. The last indicator measures the company's management commitment and effectiveness towards reducing environmental emission in its processes. It exposes the company's ability to reduce emissions, waste, water discharges and its impacts on biodiversity in the local or global community.

Furthermore, we measured our intellectual capital variable using the mean of three pillars, such as human capital, social capital and relational capital. Once again, with the awareness that IC measurement is still a questionable topic (Pedrini, 2007) we used Asset4-esg sub-pillars of economic 
and social variables to get adequate proxy measures for intellectual capital. In particular, the intellectual capital variable has been measured as follows.

IC $=($ Training and Development + Employment Quality + Community $) / 3$

Training and Development $=$ The Training and Development score is a variable that varies between 0 and 100. It measures the company's commitment and effectiveness towards providing training and development for its workers. It reflects a company's ability to raise its intellectual capital, its workforce loyalty and productivity providing an adequate development for its workforce's skills and competences. We assume that this is a good proxy for human capital because the higher is the training and development commitment, the higher will be employees' skills.

Employment Quality = The Employment Quality score is a variable that varies between 0 and 100. This variable measures a company's commitment and effectiveness towards offering high-quality employment welfare and work environments. It reveals the company's capacity to increase the workforce loyalty and productivity through ensuring adequate rewarding and fair employment treatment. Furthermore, it gives information concerning firms' long-term employment growth and stability. We assume that this variable can measure social capital because the higher is employment quality, the higher will be workers stability thus improving corporate long-term culture and routines.

Community $=$ The Community score is a variable that varies between 0 and 100. It measures a company's commitment and effectiveness towards maintaining the company's reputation within the local and global community. It reflects a company's capability to maintain its license to operate by being a good citizen, defending public health and respecting business ethics. We believe that this variable can adequately measure relational capital because the higher is firm reputation and citizenship, the higher is the capability of a firm to interact with the external environment.

Moreover, in line with previous studies in the field, we controlled for several aspects that could have an effect on both dependent variables. Company's size (Size) measured with the log transformation of total assets; Growth opportunities (Growth), measured with the year over year sales growth. We controlled also for the availability of extra-resources that may provide a higher opportunity to discretionary employ funds (to intellectual capital improvement or to environmental activities). In line with previous studies, we measured available slack in two ways: (A-slack1) with the return on asset (Waddock \& Graves, 1997) and (A-Slack2) with the working capital scaled by total asset, similarly to Arora \& Dharwadkar (2011). Furthermore, we measured the potential slack (P-slack), where potential slack refers to company's capability to raise additional cash resources, with the debt to equity 
ratio (Navarro, 1988). Furthermore, we controlled for heterogeneity in firms' operational activities, introducing a dummy variable (Subsector), which assumes the value of 1 if the company belongs to the food producer subsector and 0 if the company is a retailer. Finally, we controlled for year and country effects.

The statistical analysis includes the use of linear regression models (OLS) to analyse relations between the environmental performance (ENV) and the intellectual capital (IC). According to the purpose of the paper and to previous research (Gangi \& D'Angelo, 2016; Nelling \& Webb, 2008), dependent and explanatory variables have been measured with one-year lag. The following regression models summarizes this approach:

- Model 1: $\mathrm{ENV}_{\mathrm{t}+1}=\alpha+\beta_{1} \mathrm{IC}_{\mathrm{t}}+\beta_{2}$ Size $_{\mathrm{t}}+\beta_{3}$ Growth $_{\mathrm{t}}+\beta_{4} \mathrm{~A}-$ Slack $_{\mathrm{t}}+$ $\beta_{5} \mathrm{~A}-$ Slack $2_{\mathrm{t}}+\beta_{6} \mathrm{P}-$ Slack $_{\mathrm{t}}+\beta_{7}$ Subsector + TimeEffects + GeogreaphicalEffects $+\mu$

- Model 2: $\mathrm{IC}_{\mathrm{t}+1}=\alpha+\beta_{1} \mathrm{ENV}_{\mathrm{t}}+\beta_{2}$ Size $_{\mathrm{t}}+\beta_{3}$ Growth $_{\mathrm{t}}+\beta_{4} \mathrm{~A}-$ Slack $_{\mathrm{t}}+$ $\beta_{5} \mathrm{~A}-$ Slack $2_{\mathrm{t}}+\beta_{6} \mathrm{P}-$ Slack $_{\mathrm{t}}+\beta_{7}$ Subsector + TimeEffects + GeogreaphicalEffects $+\mu$

In which, $\alpha$ represents the intercept, $\beta_{\mathrm{i}}$ represents the coefficients of different explanatory variables, and $\mu$ represents the error term.

\section{Results}

In the next table (table 1), we report the correlation matrix for the entire sample used in this study. In particular, we are interested in the correlations between the environmental performance and measures of intellectual capital. As we can see ENV and IC are positively correlated. The following correlation analysis provides preliminary confirmation that ENV and IC are directly related. Furthermore, we can see that no high correlation has been found between dependent variables and control variables. 
Table 1. Correlation Matrix

\begin{tabular}{|c|c|c|c|c|c|c|}
\hline & & A-slack1 & P-slack & Size & Growth & A-slack 2 \\
\hline \multirow{2}{*}{ A-slack1 } & P-values & 1 & & & & \\
\hline & Sig & & & & & \\
\hline \multirow{2}{*}{ P-slack } & P-values & , 045 & 1 & & & \\
\hline & Sig &, 082 & & & & \\
\hline \multirow{2}{*}{ Size } & P-values &, 042 &, $100^{\prime \prime}$ & 1 & & \\
\hline & Sig & ,104 & ,000 & & & \\
\hline \multirow{2}{*}{ Growth } & P-values &, $084^{\prime \prime}$ & ,010 & ,028 & 1 & \\
\hline & Sig &, 001 &, 701 &, 268 & & \\
\hline \multirow{2}{*}{ A-slack2 } & P-values &, $364^{\prime \prime}$ & $-137^{\prime \prime}$ &,- 017 & $=040$ & 1 \\
\hline & Sig &, 000 & ,000 &, 517 & , 117 & \\
\hline \multirow{2}{*}{ Subsector } & P-values &, 017 &, 040 & $=010$ &, 012 &, $179^{\circ}$ \\
\hline & Sig &, 501 & ,115 & ,705 & 629 & ,000 \\
\hline \multirow{2}{*}{ ENV } & P-values & ,038 &, $141^{\prime \prime}$ &, $066^{\prime \prime}$ & $-0,054^{*}$ &,$- 091^{*}$ \\
\hline & Sig & ,137 &, 000 &, 009 &, 034 &, 000 \\
\hline \multirow{2}{*}{$1 \mathrm{C}_{+\rightarrow 1}$} & P-values &, $062^{*}$ & 032 & 032 &,- 035 &,- 042 \\
\hline & Sig & ,028 & 259 &, 255 &, 218 & ,141 \\
\hline \multirow{2}{*}{$\mathbf{E N V}_{\mathrm{i}+1}$} & P-values &, 043 & ,139" & ,031 &, 052 & $-156^{\prime \prime}$ \\
\hline & Sig & ,135 & , 000 &, 274 & ,068 & ,000 \\
\hline \multirow{2}{*}{ IC } & P-values &, $070^{-2}$ & 047 &, 049 & -043 &,- 045 \\
\hline & Sig & ,006 &, 067 &, 052 & ,091 &, 080 \\
\hline
\end{tabular}

\begin{tabular}{|c|c|c|c|c|c|c|}
\hline & & Subsector & ENV & $1 \mathrm{IC}+1$ & ENVt+1 & IC \\
\hline \multirow{2}{*}{ A-slack1 } & P-values & & & & & \\
\hline & Sig & & & & & \\
\hline \multirow{2}{*}{ P-slack } & P-values & & & & & \\
\hline & Sig & & & & & \\
\hline \multirow{2}{*}{ Size } & P-values & & & & & \\
\hline & Sig & & & & & \\
\hline \multirow{2}{*}{ Growth } & P-values & & & & & \\
\hline & Sig & & & & & \\
\hline \multirow{2}{*}{ A-slack2 } & P-values & & & & & \\
\hline & Sig & & & & & \\
\hline \multirow{2}{*}{ Subsector } & P-values & 1 & & & & \\
\hline & Sig & & & & & \\
\hline \multirow{2}{*}{ ENV } & P-values &, 023 & 1 & & & \\
\hline & Sig & 348 & & & & \\
\hline \multirow{2}{*}{$1 \mathrm{C}_{+1}$} & P-values & -041 &, $254^{\prime \prime}$ & 1 & & \\
\hline & Sig & ,133 &, 000 & & & \\
\hline \multirow{2}{*}{ ENVi+1 } & P-values &,- 003 &, $932^{\prime \prime}$ &, $268^{-\prime}$ & 1 & \\
\hline & Sig &, 922 & 0,000 & , 000 & & \\
\hline \multirow{2}{*}{ IC } & P-values &,$- 071^{-1}$ &, $297^{\prime \prime}$ &, $623^{\prime \prime}$ &, $268^{-1}$ & 1 \\
\hline & Sig & ,004 & ,000 &, 000 & ,000 & \\
\hline
\end{tabular}

To address the association between intellectual capital and environmental engagement we performed two OLS regressions. Table 2 shows results coming from the regression that has as dependent variable the environmental performance and as independent variable the intellectual capital. Results show that intellectual capital measured at time $t$ is a positive and significant predictor of the environmental performance at time $t+1$ (St. Beta $=0,235)$. Therefore, Hp1 is confirmed.

Furthermore, the model shows a positive association between environmental performance and some of the control variables such as country, 
size and subsector. In particular we can see that bigger firms and producers are more likely to have superior environmental performance. Furthermore, two out of three measures of slack resources are significant. In particular, liquidity is a negative predictor and leverage is a positive predictor of environmental engagement.

Table 2. OLS regression of corporate environmental performance and intellectual capital (Model 1)

\begin{tabular}{|c|c|c|c|c|c|}
\hline \multirow{2}{*}{$\begin{array}{c}\text { Model 1 } \\
\left(\mathrm{ENV}_{\mathrm{t}+1} \text { as dependent variable) }\right.\end{array}$} & \multicolumn{2}{|c|}{ Unstandardized Coefficients } & \multirow{2}{*}{$\begin{array}{c}\begin{array}{c}\text { Standardized } \\
\text { Coefficients }\end{array} \\
\text { Beta }\end{array}$} & \multirow{2}{*}{ t } & \multirow{2}{*}{ Sig } \\
\hline & Beta & Std Error & & & \\
\hline$\alpha$ & 14,361 & 27,711 & & ,518 & ,604 \\
\hline IC & $0,347 * *$ & ,039 & $0,235 * *$ & 8,892 & ,000 \\
\hline y1 & $-25,334$ & 26,573 &,- 283 &,- 953 & 341 \\
\hline $\mathrm{y} 2$ & $-26,842$ & 26,565 &,- 308 & $-1,010$ &, 312 \\
\hline y3 & $-27,752$ & 26,563 &,- 326 & $-1,045$ & ,296 \\
\hline $\mathrm{y} 4$ & $-26,931$ & 26,561 &,- 322 & $-1,014$ & 311 \\
\hline y5 & $-20,309$ & 26,561 &,- 244 &,- 765 & ,445 \\
\hline y6 & $-20,960$ & 26,553 &,- 267 &,- 789 & 430 \\
\hline y7 & $-21,313$ & 26,565 &,- 253 &,- 802 & 423 \\
\hline Geol & $16,066^{* *}$ & 4,864 & $0,114 * *$ & 3,303 & 001 \\
\hline Geo2 & $-6,406$ & 3,513 &,- 099 & $-1,824$ & ,068 \\
\hline Geo3 & $20,507 * *$ & 3,715 & $0,298^{* *}$ & 5,520 & ,000 \\
\hline Geo4 & $12,332 * *$ & 3,613 & $0,186 * *$ & 3,414 & ,001 \\
\hline Geo5 & 3,172 & 4,387 & ,030 & ,723 & ,470 \\
\hline Growth & $-1,679$ & 1,172 &,- 037 & $-1,433$ & ,152 \\
\hline Size & $2,168 * *$ & ,419 & $0,183 * *$ & 5,174 & ,000 \\
\hline A-slack1 &,- 008 & , 104 &,- 002 &,- 075 & ,941 \\
\hline P-slack & $0,016^{*}$ & ,008 & $0,057^{*}$ & 2,096 & ,036 \\
\hline A-slack2 & $-26,607^{* *}$ & 5,719 & $-0,140$ ** & $-4,653$ & ,000 \\
\hline Subsector & $7,990 * *$ & 1,831 & $0,127^{* *}$ & 4,364 & ,000 \\
\hline \multicolumn{2}{|c|}{$\mathrm{N}=1.209 ; \mathrm{R}$-squared $=0,21 ; \mathrm{F}=16,564 ; \mathrm{sig}=0,000$} & & & & \\
\hline \multicolumn{2}{|l|}{ Significance levels: ${ }^{*} \mathrm{p}<.05 ;{ }^{* *} \mathrm{p}<.01$} & & & & \\
\hline
\end{tabular}

Table 3, on the other side, shows that environmental engagement, measured at time $t$, is a positive predictor of the intellectual capital measured at time $\mathrm{t}+1$ (St. Beta $=0,244)$, thus confirming Hp2. In this case only one control variable (country) resulted positively associated to intellectual capital and there is no significant effect of size, financial slack, growth opportunities and sectoral characteristics. 
Table 3. OLS regression of corporate environmental performance and intellectual capital (Model 2)

\begin{tabular}{|c|c|c|c|c|c|}
\hline \multirow{2}{*}{$\begin{array}{c}\text { Model 2 } \\
\text { (ICt+1 as dependent variable })\end{array}$} & \multicolumn{2}{|c|}{ Unstandardized Coefficients } & \multirow{2}{*}{$\begin{array}{c}\begin{array}{c}\text { Standardized } \\
\text { Coefficients }\end{array} \\
\text { Beta }\end{array}$} & \multirow{2}{*}{ t } & \multirow{2}{*}{ Sig } \\
\hline & Beta & Std Error & & & \\
\hline$\alpha$ & 45,759 & 12,292 & & 3,723 &, 000 \\
\hline ENV & $0,160^{\text {** }}$ & ,020 & $0,244^{* *}$ & 8,172 & 000 \\
\hline $\mathrm{y} 1$ & 6,787 & 11,076 &, 113 & ,613 & ,540 \\
\hline y2 & 4,467 & 11,079 & ,076 & ,403 & 687 \\
\hline y3 & 4,419 & 11,081 & ,077 & ,399 & 690 \\
\hline y4 & 3,628 & 11,074 & ,065 & ,328 & ,743 \\
\hline y5 & 8,072 & 11,075 & ,145 & ,729 & ,466 \\
\hline y6 & 5,302 & 11,064 & 101 & ,479 & ,632 \\
\hline $\mathrm{y} 7$ & 3,331 & 11,072 & ,059 & ,301 & ,764 \\
\hline Geol & 1,086 & 3,498 & ,012 & ,310 & ,756 \\
\hline Geo2 & 1,829 & 2,525 & ,042 & ,725 & ,469 \\
\hline Geo3 & $-1,065$ & 2,706 &,- 023 &,- 394 & 694 \\
\hline Geo4 & 2,141 & 2,616 & ,048 & 818 & ,413 \\
\hline Geo5 & $-9,090$ ** & 3,137 & $-0,129 * *$ & $-2,897$ & ,004 \\
\hline Growth &,- 672 & 838 &,- 022 &,- 802 & ,423 \\
\hline Size &,- 257 & ,303 &,- 033 &,- 850 & ,396 \\
\hline A-slack1 & , 124 & ,074 & ,048 & 1,680 & ,093 \\
\hline P-slack & , 000 & ,005 &,- 001 &,- 050 & 960 \\
\hline A-slack2 & 1,954 & 4,082 & ,015 & 479 & 632 \\
\hline Subsector & $-1,883$ & 1,305 &,- 045 & $-1,442$ & 149 \\
\hline \multicolumn{2}{|c|}{$\mathrm{N}=1.212 ; \mathrm{R}$-squared $=0,10 ; \mathrm{F}=7,144 ; \mathrm{sig}=0,000$} & & & & \\
\hline \multicolumn{2}{|l|}{ Significance levels: $* \mathrm{p}<.05 ; * * \mathrm{p}<.01$} & & & & \\
\hline
\end{tabular}

The overall results of this preliminary study concerning the relation between intellectual capital and firms' environmental performance seems to confirm that there is a kind of virtuous circle between them.

\section{Conclusion}

Our findings contribute to existing literature both theoretically and empirically. First of all, the paper provides additional progress to prior literature analyzing the relation between intellectual capital and corporate environmentalism in a novel way. In particular, to the best of our knowledge, no one has previously investigated the possibility of a reciprocal effect between these two. Different works, as we've seen in the previous sections, tried to demonstrate that, alternatively, intellectual capital may be seen as a prerequisite for environmental performance or that this latter can be seen as a predictor of the former. Our work provides a new theoretical framework in management studies, linking together the two previously investigated constructs that apparently were in contrast one another, defining a virtuous circle of capability and resources management. 
Furthermore, empirically, the study provides evidence of the mentioned relation in a highly concerned industry such as the food one, that has not previously been investigated, linking together intellectual capital and corporate environmentalism. In particular, differently from previous studies in the field, we decided to investigate the sector as a whole (producers and retailers) in order to have a comprehensive view in terms of the entire value chain. Moreover, our results are supported by 1,200 firm-year observations that undoubtedly give robustness in confirming our results. Additionally, we used new proxies for intellectual capital defining a vector of measures that can proxy human, structural and relational capital.

Of course, this is a preliminary study and therefore has several limitations that can serve as future research objectives. In particular a more robust statistical analysis should be performed in order to provide confirmation of results. Moreover, alternative ways of measuring intellectual capital and environmental performance may be useful. For example, VAIC (Value-Added Intellectual Coefficient, developed by Pulic, 1998) may be used as a proxy of intellectual capital to confirm results according to more widely used measures. Moreover, a deeper investigation of the relation between intellectual capital and environmentalism could be done disentangling the two measures in sub-pillars. It would be interesting, for example, to see the relation between eco-product innovation, resource reduction and emission reduction on intellectual capital and, similarly, the effects of human, structural and relational capital on the environmental performance.

\section{References:}

1. Aidara-Kane, A., Angulo, F. J., Conly, J. M., Minato, Y., Silbergeld, E. K., McEwen, S. A., \& Collignon, P. J. (2018). World Health Organization (WHO) guidelines on use of medically important antimicrobials in food-producing animals. Antimicrobial Resistance \& Infection Control, 7(1), 7.

2. Ala-Harja, H., \& Helo, P. (2016). Food supply chain sustainable performance in plant decision. International Journal of Advanced Logistics, 5(1), 1-18.

3. Albertini, E. (2018). The contribution of management control systems to environmental capabilities. Journal of Business Ethics, 1-18.

4. Arora, P., \& Dharwadkar, R. (2011). Corporate governance and corporate social responsibility (CSR): The moderating roles of attainment discrepancy and organization slack. Corporate governance: an international review, 19(2), 136-152.

5. Bansal, P., \& Roth, K. (2000). Why companies go green: a model of ecological responsiveness. Academy of Management Journal, 43, 717736 
6. Barnea, A., \& Rubin, A. (2010). Corporate social responsibility as a conflict between shareholders. Journal of business ethics, 97(1), 7186.

7. Barney, J. (1991). Firm resources and sustained competitive advantage. Journal of management, 17(1), 99-120.

8. Bhimani, A., \& Soonawalla, K. (2005). From conformance to performance: The corporate responsibilities continuum. Journal of Accounting and Public Policy, 24(3), 165-174.

9. Brekke, K. A., \& Nyborg, K. (2004). Moral hazard and moral motivation: Corporate social responsibility as labor market screening (No. 2004, 25). Memorandum.

10. Brunori, G., \& Galli, F. (2016). Sustainability of local and global food chains: Introduction to the special issue. Sustainability 2016, 8, 765.

11. Chen, Y. S. (2008). The positive effect of green intellectual capital on competitive advantages of firms. Journal of business ethics, 77(3), 271-286.

12. Crifo, P., Escrig-Olmedo, E., \& Mottis, N. (2018). Corporate governance as a key driver of corporate sustainability in France: The role of board members and investor relations. Journal of Business Ethics, 1-20.

13. Dabic, M., Colovic, A., Lamotte, O., Painter-Morland, M., \& Brozovic, S. (2016). Industry-specific CSR: Analysis of 20 years of research. European Business Review, 28(3), 250-273.

14. Delmas, M. A., \& Toffel, M. W. (2008). Organizational responses to environmental demands: Opening the black box. Strategic Management Journal, 29(10), 1027-1055.

15. DiMaggio, P. J., \& Powell, W. W. (1983). The iron cage revisited: Institutional isomorphism and collective rationality in organizational fields. American sociological review, 147-160.

16. Dunlop, A. (1998). Corporate governance and control. Cima.

17. Friedman, M. (1970). A Friedman doctrine: The social responsibility of business is to increase its profits. The New York Times Magazine, 13(1970), 32-33.

18. Frooman, J. (1999). Stakeholder influence strategies. Academy of management review, 24(2), 191-205.

19. Gangi, F., \& D'Angelo, E. (2016). The virtuous circle of corporate social performance and corporate social disclosure. Modern Economy, 7(12), 1396-1418.

20. Gangi, F., Meles, A., D'Angelo, E., \& Daniele, L. M. (2019a). Sustainable development and corporate governance in the financial system: Are environmentally friendly banks less risky? Corporate 
Social Responsibility and Environmental Management, 26(3), 529547.

21. Gangi, F., Salerno, D., Meles, A., \& Daniele, L. M. (2019b). Do Corporate Social Responsibility and Corporate Governance Influence Intellectual Capital Efficiency? Sustainability, 11(7), 1899.

22. Goel, A. M., \& Thakor, A. V. (2008). Overconfidence, CEO selection, and corporate governance. The Journal of Finance, 63(6), 2737-2784.

23. Hart, S. (1995). A natural resource-based view of the firm. Academy of Management Review, 20, 986-1014.

24. Hart, S. L. (1995). A natural-resource-based view of the firm. Academy of management review, 20(4), 986-1014.

25. Hartmann, M. (2011), "Corporate social responsibility in the food sector", European Review of Agricultural Economics, Vol. 38 No. 3, pp. 297-324.

26. Holder-Webb, L., Cohen, J.R., Nath, L. and Wood, D. (2008), "The supply of corporate social responsibility disclosures among US firms", Journal of Business Ethics, Vol. 84 No. 4, pp. 497-527.

27. Jensen, M. C., \& Meckling, W. H. (1976). Theory of the firm: Managerial behavior, agency costs and ownership structure. Journal of financial economics, 3(4), 305-360.

28. Jørgensen, A., Le Bocq, A., Nazarkina, L., \& Hauschild, M. (2008). Methodologies for social life cycle assessment. The international journal of life cycle assessment, 13(2), 96.

29. Kendall, N. (1999). Good corporate governance. Institute of Chartered Accountants in England and Wales.

30. Lashgari, M. (2004). Corporate governance: theory and practice. The Journal of American Academy of Business, 5(1/2), 46-51.

31. Maloni, M.J. and Brown, M.E. (2006), "Corporate social responsibility in the supply chain: an application in the food industry", Journal of Business Ethics, Vol. 68 No. 1, pp. 35-52

32. Manning, L., \& Soon, J. M. (2016). Building strategic resilience in the food supply chain. British Food Journal, 118(6), 1477-1493.

33. Martín-de Castro G. and Salmador M. (2019). Intellectual Capital and Corporate Environmentalism. Special issue call for papers from Journal of Intellectual Capital.

34. Martín-de Castro, G., Amores-Salvadó, J., \& Navas-López, J. (2016). Environmental management systems and firm performance: improving firm environmental policy through stakeholder engagement. Corporate Social Responsibility and Environmental Management, 23, 243-256. 
35. Martín-de Castro, G., Delgado-Verde, M., Navas-López, J. and LópezSáez, P. (2011). 'Towards an intellectual capital-based view of the firm: origins and nature'. Journal of Business Ethics, 98, 649-662.

36. Martín-de Castro, G., Amores-Salvadó, J., \& Navas-López, J. E. (2016). Environmental management systems and firm performance: improving firm environmental policy through stakeholder engagement. Corporate social responsibility and Environmental Management, 23(4), 243-256.

37. Meynard, J.-M., Jeuffroy, M.-H., Le Bail, M., Lefèvre, A., Magrini, M.-B., Michon, C., 2017. Designing coupled innovations for the sustainability transition of agrifood systems. Agric. Syst. 157, 330339.

38. Mitchell, R. K., Agle, B. R., \& Wood, D. J. (1997). Toward a theory of stakeholder identification and salience: Defining the principle of who and what really counts. Academy of management review, 22(4), 853-886.

39. Navarro, P. (1988). Why do corporations give to charity?. Journal of business, 61(1), 65 .

40. Nelling, E., \& Webb, E. (2009). Corporate social responsibility and financial performance: the "virtuous circle" revisited. Review of Quantitative Finance and Accounting, 32(2), 197-209.

41. O'riordan, L., \& Fairbrass, J. (2008). Corporate social responsibility (CSR): Models and theories in stakeholder dialogue. Journal of business ethics, 83(4), 745-758.

42. O'riordan, L., \& Fairbrass, J. (2008). Corporate social responsibility (CSR): Models and theories in stakeholder dialogue. Journal of business ethics, 83(4), 745-758.

43. Pedrini, M. (2007). Human capital convergences in intellectual capital and sustainability reports. Journal of intellectual capital, 8(2), 346-366.

44. Pedrini, M. (2007). Human capital convergences in intellectual capital and sustainability reports. Journal of intellectual capital, 8(2), 346-366.

45. Pfeffer, J., \& Gerald, R. (1978). Salancik. 1978. The external control of organizations: A resource dependence perspective.

46. Porter M. E., \& van der Linde. C. 1995. Green and competitive: Ending the stalemate. Harvard Business Review, 73(5]: 120-134.

47. Porter M.E. (1980). Competitive Strategy. New York: Free Press.

48. Porter M.E. (1985). Competitive advantage. New York: Free Press.

49. Porter, M. E., \& Kramer, M. R. (2011). The Big Idea: Creating Shared Value. How to reinvent capitalism - and unleash a wave of innovation and growth. Harvard Business Review, 89(1-2).

50. Porter, M., \& van der Linde, C. (1995). Green and competitive: ending the stalemate. Harvard Business Review, Sep-Oct, 120-134. 
51. Pulic, A. (1998). Measuring the performance of intellectual potential in knowledge economy. In 2nd McMaster Word Congress on Measuring and Managing Intellectual Capital by the Austrian Team for Intellectual Potential (pp. 1-20).

52. Sharma, S., \& Henriques, I. (2005). Stakeholder influences on sustainability practices in the Canadian forest products industry. Strategic management journal, 26(2), 159-180.

53. Siano, A., Vollero, A., Conte, F., \& Amabile, S. (2017). "More than words": Expanding the taxonomy of greenwashing after the Volkswagen scandal. Journal of Business Research, 71, 27-37.

54. Stewart, T.A. (1997). Intellectual Capital: The New Wealth of Organizations; Doubleday/Currency: New York, NY, USA.

55. Våland, T., \& Heide, M. (2005). Corporate Social Responsiveness: Exploring the Dynamics of "Bad Episodes". European Management Journal, 23(5), 495-506.

56. Waddock, S. A., \& Graves, S. B. (1997). The corporate social performance-financial performance link. Strategic management journal, 18(4), 303-319.

57. Wiese, A., \& Toporowski, W. (2013). CSR failures in food supply chains-an agency perspective. British Food Journal, 115(1), 92-107.

58. Youndt, M. A., \& Snell, S. A. (2004). Human resource configurations, intellectual capital, and organizational performance. Journal of managerial issues, 337-360.

59. Zhang, D., Ma, Q., \& Morse, S. (2018). Motives for corporate social responsibility in Chinese food companies. Sustainability, 10(1), 117. 